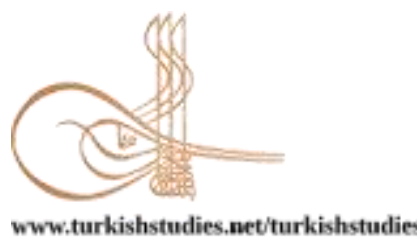

Turkish Studies

\title{
Maliyet Analizi ile İlgili Derslerin, Serbest Çalışan İç Mimarlar Açısından, Önemi Üzerine Bir Araştırma
}

\author{
A research on the Importance of Courses about Cost Analysis in Terms of Freelance Interior \\ Architects
}

\author{
Ayşe Sağsöz ${ }^{*}$ - Shirin Izadpanah** - Setenay Uçar ${ }^{* * *}$
}

\begin{abstract}
In recent years, due to the economic crisis, cost and budget management have become more and more important in interior design projects. The construction sector, which has been developing very fast in the construction sector in the country until recently, has given rise to the excess of housing and workplace. In this context, the work load for interior designers has started to increase. However, the lack of practical training in the large number of interior design departments in the country prevents the interior designers to benefit from this workload sufficiently. Failure of self-employed architects to propose an appropriate cost analysis for implementation has negative consequences for both interior architects and employers. In this study, the overall Interior Design Undergraduate education in Turkey, that the cost analysis and the deficiencies in budget management and students is a research based on the assumption that need to be reconsidered training programs to improve their skills in relation to this area. Based on this assumption, the entire interior architecture and interior design and environment related courses in budgeting and cost analysis and design program content in Turkey, obtained from the universities' web pages and analyzed. The revealed analyzes that there are not enough courses and content on this subject. The questionnaires prepared in line with this result supporting the assumption were applied to 50 interior architects who were self-employed in Antalya and received education in different universities, the results were evaluated and suggestions were developed according to these results. In addition to the courses on budget and cost analysis, it was emphasized that more information should be given to interior architects about cost analysis methods. In addition to the courses on budget and cost analysis, it was emphasized that more information should be given to interior architects about cost analysis methods.
\end{abstract}

\footnotetext{
* Prof Dr. Ayşe Sağsöz, Antalya Bilim Üniversitesi, Güzel Sanatlar ve Mimarlık Fakültesi, Mimarlık Bölümü Prof.Dr, Antalya Bilim University, Faculty of Arts and Architecture, Department of Architecture

ORCiD https://orcid.org/0000-0002-5267-2197

sagsoz@ktu.edu.tr

** Öğr. Üyesi. Dr, Shirin Izadpanah, Antalya Bilim Üniversitesi, Güzel Sanatlar ve Mimarlık Fakültesi, İç Mimarlık Bölümü

Asist. Prof. Antalya Bilim University, Faculty of Arts and Architecture, Department of Architecture

ORCID https://orcid.org/0000-0001-8395-7155

shirin.izadpanah@gmail.com

**** Arş. Gör. Setenay Uçar, Antalya Bilim Üniversitesi, Güzel Sanatlar ve Mimarlık Fakültesi, İç Mimarlık Bölümü

Research Asist. Antalya Bilim University, Faculty of Arts and Architecture, Department of Architecture

ORCiD https://orcid.org/0000-0001-8395-7155

setnay.ucar@antalya.edu.tr

Cite as/ Atıf: Sağsöz, A., Izadpanah, S., Uçar, S. (2020). Maliyet analizi ile ilgili derslerin, serbest çalışan iç mimarlar açısından, önemi üzerine bir araştırma. Turkish Studies, 15(3), 2127-2139 https://dx.doi.org/10.29228/TurkishStudies.41837

Received/Geliş: 19 February/Şubat 2020

Accepted/Kabul: 20 June/Haziran 2020

Copyright $\odot$ MDE, Turkey

Checked by plagiarism software

Published/Yayın: 25 June/Haziran 2020

CC BY-NC 4.0
} 
Structured Abstract: When interior architects fail to offer a realistic cost, they lose customer confidence as well as their professional confidence. On the other hand, an unrealistic cost may incur additional costs in the process and as a result the customer may suffer economic damage. Considering the importance of budget analysis in this respect, it will be a positive initiative to develop the skills of Interior Architecture students in calculating the cost of building. In Turkey, summer internships to help students gain practical experience before graduation to Interior Architecture, although mandatory compulsory courses in undergraduate programs, internships, students cannot overcome the shortcomings in this respect.

In this study, the overall Interior Design Undergraduate education in Turkey, that the cost analysis and the deficiencies in budget management and students is a research based on the assumption that need to be reconsidered training programs to improve their skills in relation to this area. Based on this assumption, the entire interior architecture and interior design and environment related courses in budgeting and cost analysis and design program content in Turkey, obtained from the universities' web pages and analyzed. The revealed analyzes that there are not enough courses and content on this subject. The questionnaires prepared in line with this result supporting the assumption were applied to 50 interior architects who were self-employed in Antalya and received education in different universities, the results were evaluated and suggestions were developed according to these results.

Although the study showed that the skills in cost analysis were very important for the profession, the number and content of courses in the Interior Architecture Undergraduate Programs showed that they were not sufficient to improve students' budgetary skills. This result is a clear indication of the need for qualitative and quantitative improvement of the structure of courses in undergraduate programs in relation to cost analysis and budget management. It is also emphasized that the interior architects should be given more information about the methods they use for both education and application. According to the results obtained, most of the participants stated that they believed that there were gaps and deficiencies related to cost analysis in the undergraduate programs of interior architecture. Compulsory summer internships in the second and third grades are not sufficient for students to completely overcome their deficiencies in this subject.

Budget calculation and cost analysis is an important issue for interior designers. Due to unexpected situations during the construction phase, it is normal for the total cost to change. However, if the reason for the change in project cost is the lack of knowledge of the interior architect in terms of cost and budgeting, the result will harm the interior architect's career and income. interior architecture degree programs in Turkey is increasing every year, which increases the difficulties in terms of ability to find a place in this sector. Having knowledge and skills in calculating a suitable cost for projects is even more important to help interior architects survive in the current market. Although the survey study conducted with 50 interior architects revealed that the participants believed that their ability to perform cost analysis was very important for their professional career, it was also found that most of them did not have sufficient information to perform cost analysis after graduation.

In line with this result, the structure of the courses in interior design undergraduate programs needs to be developed in order to provide sufficient content related to cost analysis and budget management. This research also emphasizes the importance of considering cost analysis in the real market and developing lessons based on the realities of the interior design profession. Another interesting result of this study is that interior architects work with artisans and construction companies instead of interior architecture / architecture companies to develop their skills in cost analysis.

This result indicates that there is a lack of methodologies related to cost analysis in interior architecture and architecture offices. These results also point to some problems related to cost analysis in the market. The reason why the participants could not talk about a methodology in the questionnaire may be based on the fact that they cannot follow a standard path or still do not have enough information to use a particular methodology. In interior design education, as in all design areas, it is not enough to develop the design ability of the student and to transfer the design in two or three dimensions. While the internships they make take their first steps into the world of practice, they will help them develop further with the knowledge and skills they need to receive in education.

Keywords: Interior Architect, Undergraduate Education of Interior Architecture, Cost Analysis, Professional Practice 
Öz: Son y1llarda ekonomik kriz nedeniyle, iç mimarlık projelerinde maliyet ve bütçe yönetimi giderek daha önemli hale gelmeye başlamıştır. Ülkede son yıllara kadar oldukça hızlı gelişen inşaat sektörü, özellikle konut ve işyeri fazlalığını doğurmuş, yeni yapılaşmalara yönelme yerine mevcudu yenileme ve değerleme çalışmalarını hızlandırmıştır. Buna paralel olarak iç mimarlara düşen iş imkânı ve yükü artmaya dolayısıyla da iç mimarlık alanı daha fazla ilgi görmeye başlamıştır. Ancak, ülkede oldukça fazla sayıda açılan iç mimarlık bölümlerinde uygulamaya yönelik eğitim ayağının eksikliği iç mimarların bu iş imkânlarından yeterince yararlanmalarına engel olmaktadır. Serbest çalışan mimarların uygulama için uygun bir maliyet analizi önerememeleri hem iç mimarlar hem de işverenler açısından olumsuz sonuçlar meydana getirmektedir. Çalışma, Türkiye'de genel olarak İç Mimarlık Lisans eğitiminde, maliyet analizi ve bütçe yönetimi konusunda eksikliklerin olduğuna ve öğrencilerin bu alanla ilgili olarak becerilerini geliştirmek için eğitim programlarının yeniden ele alınması gerektiği varsayımına dayalı bir araştırmadır. Bu varsayıma dayanarak, Türkiye'deki tüm iç mimarlık ve iç mimarlık ve çevre tasarım programlarındaki bütçe ve maliyet analizi ile ilgili dersler ve içerikleri, üniversitelerin web sayfalarından elde edilmiş ve analiz edilmiştir. Yapılan analizler bu konuda yeterli sayıda ve içerikte derslerin olmadığını ortaya koymuştur. Varsayımı destekleyen bu sonuç doğrultusunda hazırlanan anketler, Antalya kentinde serbest çalışan, farklı üniversitelerde eğitim almış 50 iç mimara uygulanmış, elde edilen sonuçlar değerlendirilmiş ve bu sonuçlara göre öneriler geliştirilmiştir. Çalışmada bütçe ve maliyet analizleri ile ilgili derslerin yanı sıra, iç mimarlara maliyet analizi yöntemleri hakkında da daha fazla bilgi verilmesi gerektiğine de vurgu yapılmıştır.

Anahtar Kelimeler: İç Mimar, İç Mimarlık Lisans Eğitimi, Maliyet Analizi, Mesleki Uygulama

\section{Giriş}

İç mimarlık uygulamalarında işverenler genellikle ya bütçelerini kendileri belirleyerek bir tasarım talep etmekte ya da iç mimarların ürettikleri tasarım seçenekleri ve yaklaşık olarak belirledikleri maliyetler doğrultusunda tercih yapmaktadırlar. Bu nedenle iç mimarların işverenin belirlediği ekonomik sınırlar içinde tasarım yapabilme veya yaklaşık maliyeti belirleyerek işverene sunma becerisine sahip olmaları gerekmektedir; doğru bir maliyet analizi hazırlama bilgisinin eksikliği her iki taraf için de ciddi zararlara neden olabilmektedir. İç mimarların bir iş için müşteriye çok yüksek veya çok düşük bir bedel önermeleri, ileriye yönelik olarak bir takım ekonomik sıkıntılara neden olabileceği gibi, işveren-iç mimar ilişkisi ve güvenini de olumsuz yönde etkileyecektir. Bu olumsuzlar genellikle iç mimarların maliyetler hakkında yeterli bilgiye ve beceriye sahip olmamalarından kaynaklanmaktadır.

Piotrowski (1992)'nin belirttiği gibi ekonomik göstergelerin çok sık değiştiği bir ülkede, özellikle uygulama sürecinde, maliyetlerin değişmesi ve özellikle yükselmesi nedeniyle büyük projeler için tam bir maliyet hazırlamak çok riskli bir görevdir. Ancak, iç mimarların tasarım aşamasının başlangıcında yaklaşık maliyetleri hesaplamasına yardımcı olan pek çok yöntem vardır. $\mathrm{Bu}$ yöntemlerin ve kullanımın öğretilmesi iç mimarlık eğitiminde en önemli noktalardan biridir.

Türkiye'de, iç mimarlık lisans programlarının çoğunda, maliyet analizi içeren dersler sınırlı sayıda olup, var olanlar ise öğrencilere genellikle son sınıflarda verilmektedir. Burada amaç, öğrencileri mezuniyet zamanına yakın dönemde bütçe ve maliyetler hakkında bilgilendirmektir. Sınırlı sayıdaki dersler zorunlu stajlar ile desteklenmekte, ancak tasarıma yönelik derslerde yaklaşık giderleri hesaplamaya yardımcı olan yöntemler yeterince ve uygulamalı olarak verilmemektedir. Bu nedenle iç mimarların çoğu, mezun olduktan sonra bütçe analizi konusunda yeterli eğitim almadıkları için büyük sorunlar yaşamaktadırlar (Izadpanah, 2018).

İç mimarlık uygulamalarında, yaklaşık maliyeti hesaplamak tasarımdan sonraki ilk aşamadır ve genellikle programlama olarak veya ön tasarım aşaması olarak tanımlanır. Tasarım projesinde bütçeleme, sunum için görüntü oluşturma kalitesinden uygulamalardaki detayların kalitesine kadar tasarımın tüm yönlerini etkilemektedir. İç mimarlık projelerinde maliyet analizi genellikle malzeme, kaplama, mobilya ve işçilikle ilgilidir. Bu malzemeleri üretmek için sektör gün geçtikçe büyüdüğü 
için, iç mimarlar, tutarlı bir bütçeleme programı hazırlamak ve en iyi kararları almak için mevcut maliyetler hakkındaki bilgilerini sürekli güncellemek zorunda kalmaktadırlar (Mitton, 2003).

Piotrowski (1992) ise iç mimarlık projelerinde kesin ve sabit bir rakam olmadığı ve beklenmeyen durumlar için esneklik payı bırakılması gerektiği için proje giderleri için de yaklaşık bir bütçeleme hazırlanması gerektiğini belirtmektedir. İç mimarların proje giderleri için yaklaşı bir bütçe hazırlamalarına yardımcı olabilmesi için iki tür bütçeleme yöntemi önermektedir. $\mathrm{Bu}$ yöntemler aşağıdaki gibidir:

- Metrekare bütçeleme: İç mimarlar metrekare başına düşen temel inşaat maliyetlerini periyodik olarak takip ederler. Bu yöntemi takip etmek için, yakın çevrede ya da bölgede yapılmış ve hesaplanmış, benzer metrekaredeki projelerin inşaat maliyetini göz önünde bulundurmaları gerekir. Ayrıca bölgedeki diğer firmaların bitirdikleri projelerin maliyet kayıtları hakkında da iyi araştırmalar yapmak zorundalardır.

- Tipik bütçeleme: Bu yöntemde iç mimarlar, benzer işlevler için tipik bir bütçeleme tanımlayabilir ya da farklı işlevler için tamamen farklı bir bütçeleme önerebilir ve yaklaşık bir bütçe sunabilirler. Böylece, işveren farklı seçenekleri keşfetme ve en çok beğendiği veya bütçesine uygun düzenlemeye karar verme şansına sahip olacaktır.

Ancak, bu yöntem genellikle tasarımcının iş tecrübesine ve yeterli proje bilgisine sahip olmasına bağlıdır. Her iki yöntem de iç mimarlara eğitim aşamasında verilebilirse pazarı erken dönemde tanımayı öğrenmeleri sağlanabilir.

Improvenet (2018) ve Martin (2019)' a göre maliyet analizi yapıldıktan sonra iç mimarların ortaya çıkan toplam ücrete kendi ücretlerini de dahil edebilmeleri için belirli yöntemler vardır ve bu yöntemler aşağıdaki gibi sınıflandırılabilirler:

- Saatlik Ücret: Küçük projeler için kolay ve yararlı bir yöntemdir. Bu yöntem, iç mekân tasarımcılarının mekânı ziyaret etmeleri, tasarım üzerinde çalışmaları, kullanılacak malzemeleri sağlamalarını içerir ve genel olarak, ücret tasarımcıların projede çalıştığı toplam süreye göre hesaplanır.

- Sabit Ücret: Projenin başından sonuna kadar tamamlanmasına kadar yapılacak hizmet karşıllğında sabit bir ücret alınabilmektedir.

- Metrekare Üzerinden Ücret: Ücret, metrekare başına değerlendirilmektedir.

Komisyon Ücreti: İç mimar, mobilya ve malzemeleri indirimli olarak satın almakta ve işverene sunduğu bedeli yüksek tutarak aradaki farkı kendi ücreti olarak almaktadır.

Yüzde Ücreti: İç mimar, projenin toplam maliyetinden yüzde olarak ücret almaktadır.

Michaels ve Wood (1989)' a göre tasarım maliyeti, tasarımcının mevcut durumda etkili bir maliyet yönetimi için önerdiği başka bir felsefe olduğunu belirtmektedirler. Bu yöntem gerçekçi maliyet sağlamak için gösterilmiş ve tasarımın maliyete dayanması yerine, maliyetin tasarıma dayanmasını sağlamaktadır. Çünkü maliyetin kendisi ana tasarım girdisidir ve amaçlanan bütçeye dayalı tasarım kısıtlarını tanımlamak için bir yol sağlamaktadır. Ancak, bu yöntemi kullanarak maliyet analizi çıkarmak ciddi bir zaman ve sıkı bir çalışma ile tecrübe gerektirmektedir.

Türkiye'de iç mimarlar odasının belirlediği İçmimarlık Hizmetleri Hesaplama Esasları aşağıdaki gibidir;

1. İçmimarlık Hizmet Bölümü Oranları

a) Rölöve, \% 10

b) Ön Proje, \% 20 
c) Kesin Proje ve Malzeme Seçimi, \% 30

d) Uygulama Projesi - Sistem Detaylar1 - İmalat Detayları, \% 35

e) Mahal Listesi Metrajlar ve İş yapım Programı hazırlanması, \% 5'dir.

2. Proje en az ücret bedeli formülü; Proje Asgari Ücreti (PAÜ) = Yapının Yaklaşı m2 alanı

(YYA) x Birim Maliyet; YTL / m2

(BM) x PİD oranı x İçmimarlık Hizmet Bölümü Oranı (HBO) x

Koordinasyon Kat Sayısı (KK) şeklindedir (IMOB).

İç mimarlık projesi için bütçe hazırlama ile ilgili önemli bir başka konu, işveren ve iç mimarın toplam bütçe hakkındaki uyuşmazlıklarıdır. İç mimarların gelecekte oluşabilecek uyuşmazlıkları önlemek adına sözleşmede görüşülen tutara eklemeler yapmamaları ve anlaşma yapılan miktarlarda büyük değişikliklerden kaçınmaları gerekmektedir. Bu bağlamda proje yönetimi hem mimari hem de iç mimari projelerde önemli bir gerekliliktir. Proje yönetimi; kaynak planlaması, maliyet tahmini, bütçe oluşturma ve maliyet kontrolü dahil olmak üzere dört aşamalı olarak sınıflandırılabilir. $\mathrm{Bu}$ aşamaların her birini gerçekleştirmek ciddi bir görevdir. Bu nedenle büyük projelerde, iç mimarlar veya mimarlar maliyetleri kontrol edebilecek ve yönetmekle ilgilenebilecek uzmanları işe almayı tercih etmektedirler.

Bu konuda iyi bir temele sahip olan iç mimarlar, pazardaki becerilerini daha erken ve daha kolay tamamlayabileceklerdir. Proje yönetimi ve maliyet kontrolü, iç mimarın eğitimleri sırasında kazanmaları gereken en önemli bilgi ve becerilerden biridir. Bu nedenle proje yönetimi ve maliyet kontrolü derslerinin iç mimarlık lisans programında yer alması gerekmektedir.

Türkiye'de iç mimarlık ve iç mimarlık ve çevre tasarımı alanlarında 62 lisans programı bulunmaktadır. Bu programların web siteleri incelendiğinde 10'unun müfredatlarını web sitelerine koymamış olduğu, 16 programın ise bütçe yönetimi ve maliyet analizi ile ilgili belirli bir dersi bulunmadığı saptanmıştır. Sadece 36 program maliyet ve bütçeleme ile ilgili içeriğe sahip ders içermektedir.

Bozkurt ve Kuruoğlu (2017) tarafindan yapılan bir çalışmada, projelerde yaklaşık maliyet sağlayamamanın en önemli nedeninin tasarımcıların maliyet ve bütçelemeye ilişkin bir birikime sahip olmamaları olduğu belirlenmiştir. Bu nedenle çalışma Türkiye'deki iç mimarlık lisans programlarında verilen bütçe ve maliyet analizi ile ilgili dersler ve içerikleri ile ilgili olarak, Antalya'da serbest olarak çalışan iç mimarlar üzerinden görüşlerini ve memnuniyetlerini belirleme üzerine odaklanmıştır.

\section{Yöntem}

Son yıllarda ekonomik kriz nedeniyle, iç mimarlık alanında maliyet ve bütçe yönetimi giderek daha önemli hale gelmeye başlamıştır. Ülkemizde son yıllara kadar oldukça hızlı gelişen inşaat sektörü konut ve işyeri fazlalığını doğurduğu gibi yeni yapılaşmaların yanında mevcutları yenileme çalışmaları da hızlanmaya başlamıştır. Özellikle merkezi bölgelerdeki iş yerleri ile yerleşimler ekonomik değerlerini korudukları için buralardaki yapılarda yenilemeler de giderek artmıştır. İç mekânlardaki yenilemeler iç mimarlara düşen iş yükünü de artırmaya başlamıştır. Ancak, ülkemizde oldukça fazla sayıda açllan iç mimarlık bölümlerinde maliyet ve bütçe yönetimine yönelik derslerin azlığı ya da içerik eksikliği özellikle yeni mezun iç mimarların bu paydan yeterince yararlanmasına engel olmaktadır.

$\mathrm{Bu}$ bağlamda, serbest çalşsan iç mimarlara bütçeleme becerileri, yeterlilikleri ve eksikliklerine odaklanan bir anket çalışması uygulanmıştır. Anketlerden elde edilen bulgulara 
dayanarak maliyet ve bütçe yönetimine ilişkin derslerin eğitimdeki konumu ve uygulamadaki eksiklikleri, Antalya ilinde çalışan serbest mimarlara yapılan anketlerle sorgulanmış, anketler değerlendirilmiş ve öneriler geliştirilmiştir.. Mevcut çalışmayı oluşturmak için anket 50 iç mimara uygulanmıştır. Anketin içeriği, katılımcıların üç ana konuyla ilgili memnuniyetleri ile ilgili sorulardan oluşmaktadır. Bunlar;

○ İç Mimarlık Lisans Programları için maliyet analizinin önemi,

○ Maliyet analizi ile ilgili kazanımları eğitim süresi boyunca bilmenin önemi,

- Katılımcıların mezun olduktan sonra maliyet analizi yapma becerilerinin var olmasının önemi olarak sıralanabilir.

Anket Antalya'da serbest olarak çalışan iç mimarlara uygulanmıştır. Antalya ilinin seçilmesinin en önemli nedeni kıyı kenti olması ve buna bağlı olarak turizm kenti olmasıdır. Her turizm sezonu sonunda özellikle konaklama, yeme-içme mekânlarında ve genellikle de iç mekânlarda yenileme çalışmalarının yoğun olması ekiplerde iç mimarların çoğunlukta yer almasına neden olmaktadır. Anketler Basit Tesadüfi Örnekleme yöntemi ile seçilen, Antalya'da meslek odasına kayıtlı (iç mimarlar odası kısaca IMOB) toplam 400 iç mimardan, 50 iç mimara uygulanmıştır.

$\mathrm{Bu}$ yöntemin kullanılabilmesi için ele alınan problemlerle ilgili bilgilerin evrene göre benzeşik (homojen) olması gerekir. Basit tesadüfi örneklemede öncelikle evrenin tüm öğelerini içeren bir örneklem çerçevesi yapılmalıdır (Mertens, 2014). Genellikle bir liste halinde oluşturulan örneklem çerçevesinde araştırmacı her öğeye bir numara vermektedir. Daha sonra araştırmac1 örneklemin içinde olmasını istediği öge sayısı kadar tesadüfi sayılar üretir veya öğeleri oluşturduğu listeden rastgele seçebilmek için bir bilgisayar programı ya da tesadüfi sayı listelerini kullanır (Baltac1, 2018).

Anket, konuyu sınırlamak ve ankete katılanların eksiksiz doldurmaları amacıyla, 8 soru ile sinırlı tutulmuştur. Katılımcılara ilk sırada;

- İç mimarlık mesleğinde maliyet analizinin önemi,

- İç mimarlık eğitim programlarında maliyet analizi eğitiminin uygulama ile benzerlikleri,

- Lisans programları sırasında maliyet analizi ile ilgili herhangi bir eğitim alıp almadıkları,

- Mezuniyet sonrasında, bir maliyet analizi yapma konusunda, edindikleri bilgi ve becerilerinden memnuniyet düzeyleri sorulmuştur. $\mathrm{Bu}$ ilk dört soru, katılımcıların profesyonel meslek kariyerleri için maliyet analizinin önemi hakkında fikir sahibi olup olmadıkları ve bu konu hakkında aldıkları eğitimden memnun olup olmadıklarının elde edilmesi amaçlanmıştır.

- Daha sonra, mezun olduktan sonra maliyet analiziyle ilgili becerileri ve bilgileri ile ilgili memnuniyet düzeylerini gösterecek sorular sorulmuştur. Bunun nedeni, eğitim programlarının, pazardaki gerçek uygulamalar için, iç mimar adaylarını pazara hazırlamada başarılı olup olmadıklarını öğrenmektir. Bu nedenle katılımcının bedeller hakkındaki bilgileri ve mezun olduktan sonra işverenlerine bütçe hesabı öncesi teklif sunma konusundaki bilgilerine olan güvenleri test edilmiştir.

- Anketin son bölümünde katılımcılara eğitimin maliyet analizi ile ilgili boşluk ve eksiklik düzeyleri ile bu boşluğu mezun olduktan sonra nasıl doldurduklarını sorulmuştur. Ayrıca, projelerinin maliyetini hesaplamak ve bir bütçe özeti hazırlamak için kullandıkları yöntemleri ve programları paylaşmaları istenmiştir. Bulguları değerlendirmek için SPSS kullanılmış ve araştırma hipotezi nihai istatistiklere dayanarak tartışılmıştır. 


\section{Bulgular}

- Katılımcılara iç mimarlık mesleği için maliyet analizinin önemli olup olmadığı sorusuna verilen cevaplara göre, ankete katılanların \% 92'si maliyet analizi yapabilmenin önemli olduğunu belirtmiştir. Bu oranın \% 78'i maliyet analizi yapabilmenin çok önemli olduğu şeklinde cevaplamıştır. Bu sonuç, profesyonel yaşamda mesleki açıdan maliyet analizinin önemini vurgulamaktadır, (Şekil 1).

İç mimarlık eğitim süresince maliyet analizi ile ilgili eğitim almayanların \%64'ü iç mimarlık eğitiminde maliyet analizi dersinin çok önemli olduğu, \%22'si önemli olduğu, \%7'si eğitimin öneminin orta ve \%7'si eğitimin az önemli olduğunu ifade etmiştir.

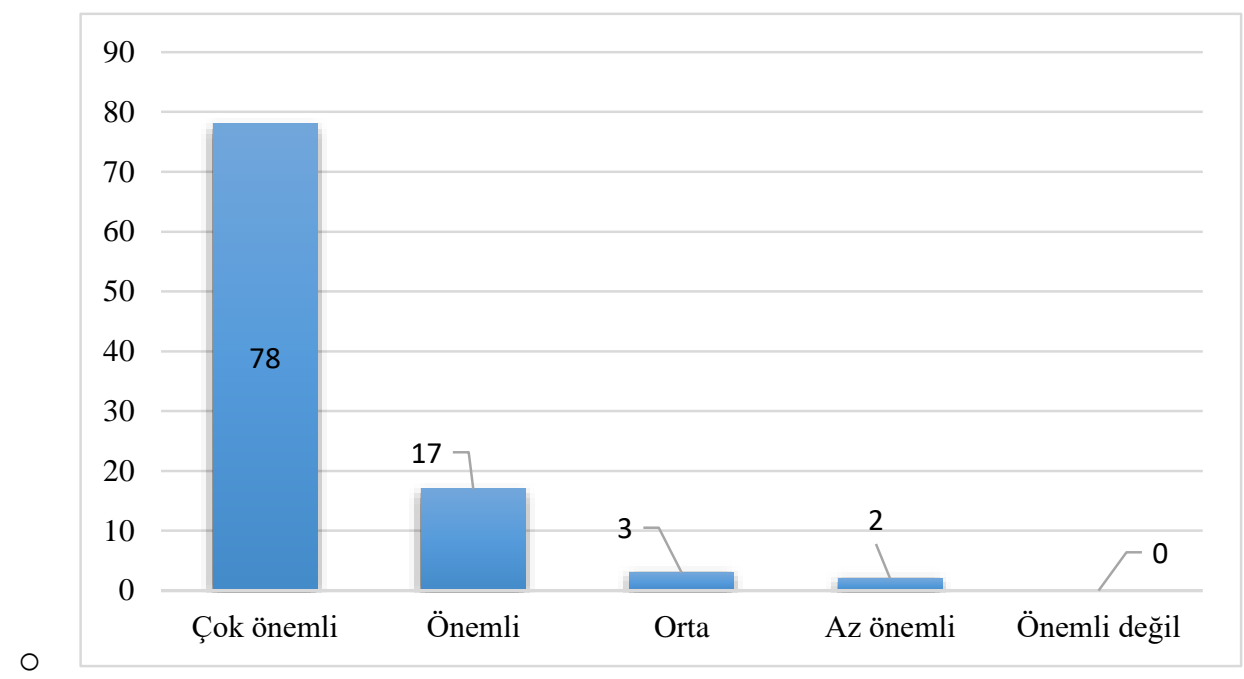

Şekil 1: Katılımcıların iç mimarlık mesleğinde maliyet analizinin önemine verdikleri cevaplar.

- İkinci soruda, katılımcılara iç mimarlık eğitim programında, maliyet analizine ilişkin aldıkları dersler ile uygulamalarda yaptıkları arasındaki benzerlik sorulmuştur. Bu soruya cevap veren katılımciların \%33,5'i benzer olduğunu değerlendirirken, 32.7'i bu ilişkiyi orta derecede, \% 32.8'i ise zayıf olarak değerlendirmiştir. Katılımcıların çoğu maliyet analizi ile ilgili aldıkları eğitimlerin, sektörde gördükleri uygulama arasındaki benzerliğin tam olarak örtüşmediğini belirtmişlerdir, (Şekil 2).

İç mimarlık eğitim süresince maliyet analizi ile ilgili eğitim almayanların \%79'u tasarımda maliyet ile ilgili mevzuatla çalışırken karşılaşmış, \%14 ‘ü stajda ve \% 7’si hiç karşılaşmamıştır. Bu veriler araştırma hipotezini desteklemektedir. 


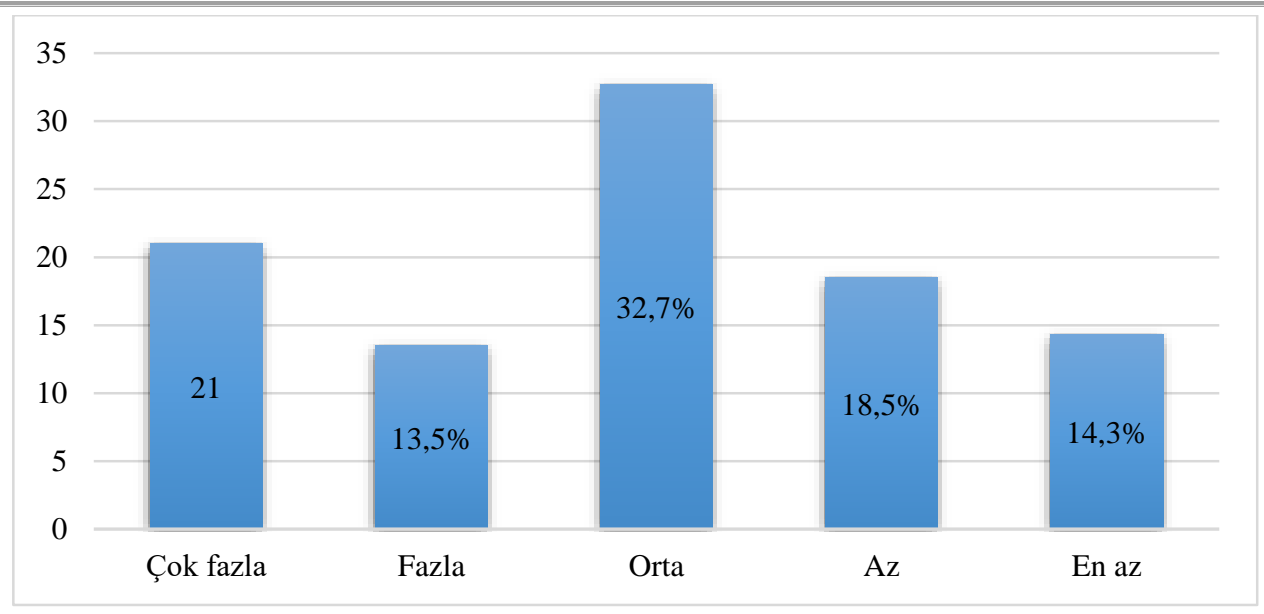

Şekil 2: Katılımcıların iç mimarlık eğitimi programlarında maliyet analizi ile ilgili eğitimin sektördeki bütçe yönetimi gerçeğiyle olan benzerliğine verdikleri cevaplar

- Katılımcılara eğitimlerinde "maliyet analizi" ile ilgili herhangi bir ders alıp almadıkları sorulduğunda \%68'i bu soruya evet cevabını vermiştir (Şekil 3). Bu veriler, iç mimarlık lisans programı müfredatı üzerine yapılan araştırmadaki veriler ile paraleldir.

İç mimarlık eğitim süresince maliyet analizi ile ilgili eğitim almayanların \%65 mezuniyet sonrası mevzuata hakim olmadıklarını belirtmiştir. Katılımcıların \%7'si mevzuata az hakim iken, \%14'ü orta, \%7'si hakim, kalan \%7'si çok hakim olduğu cevabını vermiştir.

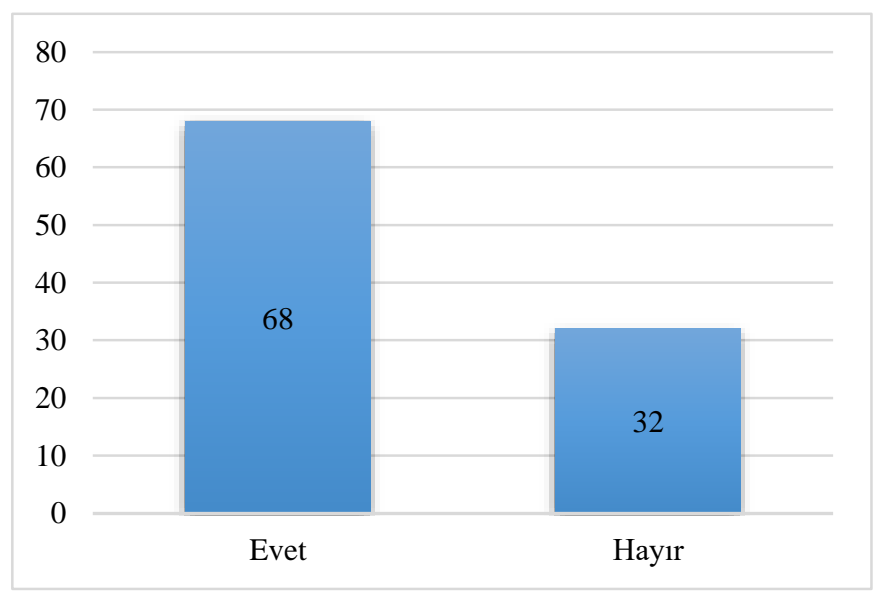

Şekil 3: Katılımcıların iç mimarlık eğitimi süresince, maliyet analizi konusu ile ilgili herhangi bir eğitim alıp almadıklarına ait cevaplar

- Kat1limcilardan mezun olduktan sonra maliyet analizi yapma konusundaki bilgi ve becerilerinden duydukları memnuniyeti değerlendirmeleri istenilmiştir. \% 20 'si bilgi ve becerilerinin zayıf ya da çok zayıf olarak, \% 43'ü ise bilgi ve becerilerinin ortalama bilgi seviyesinde olduğunu belirtmiştir (Şekil 4).

$\mathrm{Bu}$ sonuçlar, maliyet analizi ile ilgili derslerin isimlerinin programlarda yer almalarına rağmen, çoğunun maliyet analizi için gerekli temel bilgileri ve bütçe özeti çıkarma becerilerini tam olarak geliştiremediklerini ve büyük olasılıkla mezunların profesyonel yaşamlarının başlangıcında bir bütçe özeti hazırlarken zorluklar yaşadıklarını ortaya koymaktadır. Bu alanda eğitim almış olmalarına rağmen memnuniyet düzeylerinin bu olması ders içeriklerinin yeniden ele alınması gerektiğine işaret etmektedir. 
İç mimarlık eğitim süresince maliyet analizi ile ilgili eğitim almayanların \%50'si pazardaki güncel bedellendirmeye hakim olmadığını, \%7'si az, \%22 ‘si orta, \%14'ü iyi ve \%7si çok hakim olduğunu belirtmiştir.

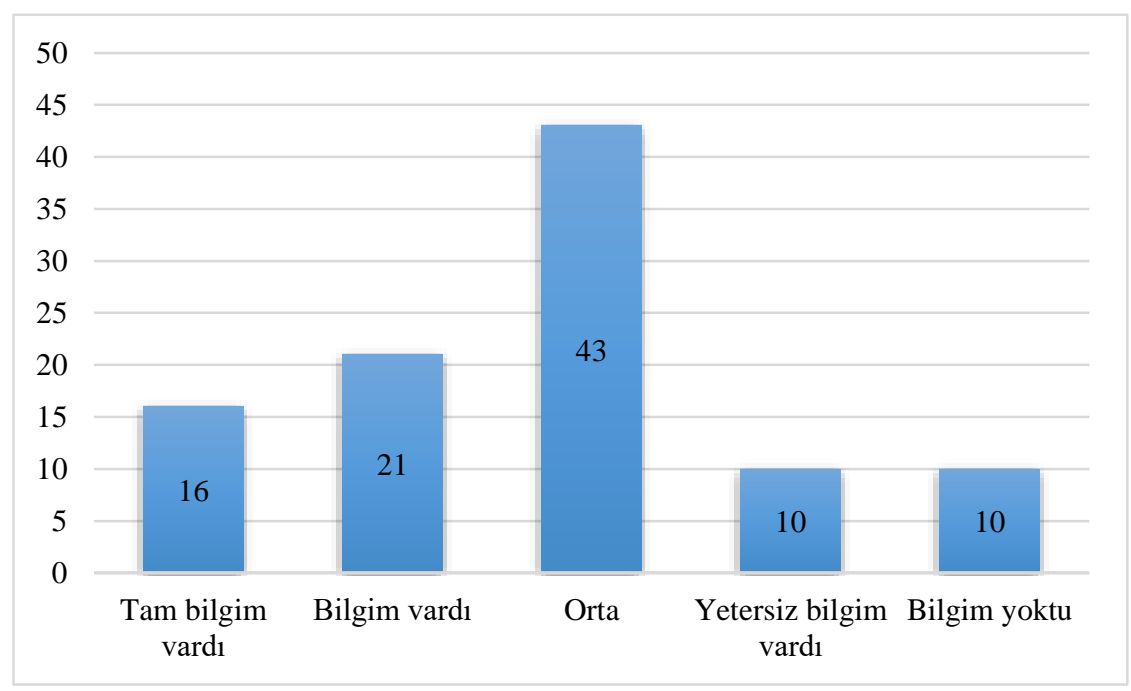

Şekil 4- Katılımcıların maliyet analizi yapma konusundaki bilgi ve becerilerinden memnuniyet düzeyleri

- Katılımciların mezun olduktan hemen sonra maliyet analizi konusundaki bilgi ve becerileri hakkında daha iyi bir bakış açısı elde etmek için mezun olduktan sonra işverenleri için bir teklif hazırlayıp hazırlayamadıkları soruldu. Katılımcıların önceki soruya cevap vermelerine benzer şekilde çoğu, bir maliyet analizi teklifi hazırlayamadıkları cevabını vermiştir. $\mathrm{Bu}$ noktada, katılımcıların çoğu mesleki kariyerleri için maliyet analizinin önemine inanmalarına rağmen, lisans eğitiminde maliyet analizi ile ilgili eğitim alırken bu konu hakkında yeterli bilgiye sahip olmadıkları cevabını vermişlerdir (Şekil 5).

İç mimarlık eğitim süresince maliyet analizi ile ilgili eğitim almayanlar mezuniyet sonrasında \%22'si az yetkin, \%42'si orta, \%22'si yetkin ve \%14'ü çok yetkin duruma geldiklerini belirtmiştir.

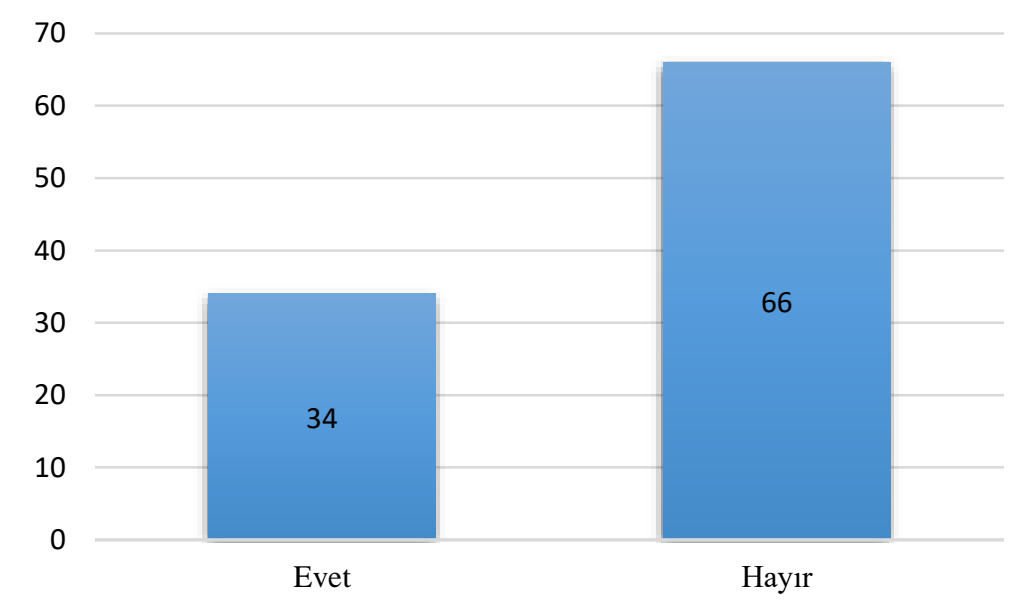

Grafik 5- Katılımcılar mezun olduktan sonra işverenlerine bütçe hesabı öncesi bir ön teklif sunma konusundaki güvenleri 
- Mezun olduktan sonra pazardaki bedel bilgileri hakkında verilen cevaplar \% 6'si tam, \% 12'si bilgili, \% 30'u orta derecede \% 16's1 yetersiz bilgiye sahip olduğu ve \% 34'ü hiç bilgisinin olmadığı şeklindedir. Yani toplamda yüzde \% 65,7'si pazardaki bedellendirme konusunda yeterli bilgiye sahip değildir (Şekil 6). Bu sonuç, öğrencilerin eğitimleri sırasında, yapmış oldukları stajlara rağmen, bütçe açısından pazardan haberdar olmadıklarını ve öğrencilerin tasarım projeleri için malzeme seçerken bedel konusunda araştırma yapmadıklarını ya da öğrencilerden bu konuda bilgi istenmediğini ortaya koymaktadır.

İç mimarlık eğitim süresince maliyet analizi ile ilgili eğitim almayanların (mezuniyetten hemen sonra) $\% 15$ 'i işverene teklif verebilmeye yetkin olduğunu belirtirken, $\% 85$ 'i teklif vermeye yetkinliği olmadığı cevabını vermiştir.

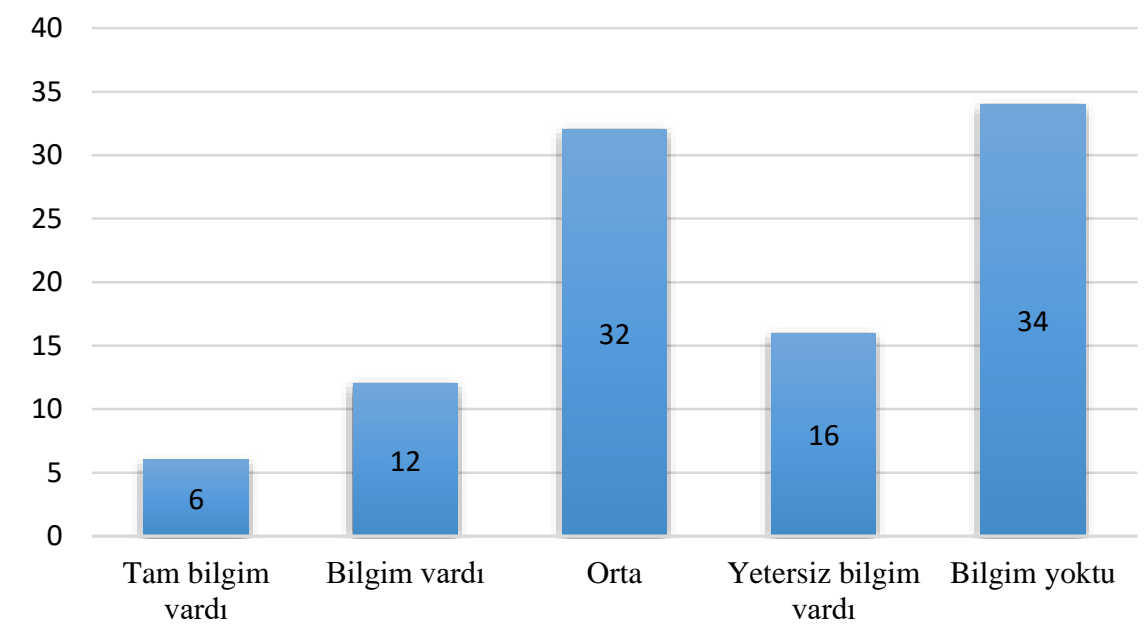

Şekil 6- Katılımcıların mezun olduktan sonra pazardaki bedeller hakkındaki bilgiye sahip olup olmadıkları hakkında cevaplar

- Ayrıca, katılımcılara iç mimarlık lisans programlarının içeriğinde maliyet analiziyle ilgili boşluklar ve eksiklikler sorulmuştur. \% 81'i maliyet analiziyle ilgili eksiklikler olduğuna belirtmiştir.

İç mimarlık eğitim süresince maliyet analizi ile ilgili eğitim almayanların\%85'i konunun eksikliğini duyduklarını kabul ederken \%15'i eksikliğini hissetmediklerini vurgulamıştır (Şekil 7).

$\mathrm{Bu}$ sorudan elde edilen veriler araştırma hipotezini de desteklemektedir. Katılımcılar, bütçe ve maliyet analizi ile ilgili yeterli bilgi içermemesini eğitimin içeriğine bağlamışlardır. Soruyu evet olarak cevaplayan katılımcılardan, bir maliyet analizi yapma ve bir bütçe özeti hazırlama konusundaki becerilerini nasıl geliştirdiklerini ifade etmeleri istenmiştir. Bu cevapların toplamı içerikteki benzerliklerine göre sınıflandırılmıştır. Son sınıflamaya göre, katılımcıların\% 77.5 'i inşaat sektöründeki tecrübeli bireylerle çalışarak y1llarca bütçe hesaplama becerilerini geliştirdiklerini, diğerleri ise çalışma ortamlarında ve meslektaşlarıyla etkileşime girerek gerekli becerileri geliştirdiklerini belirtmişlerdir. 


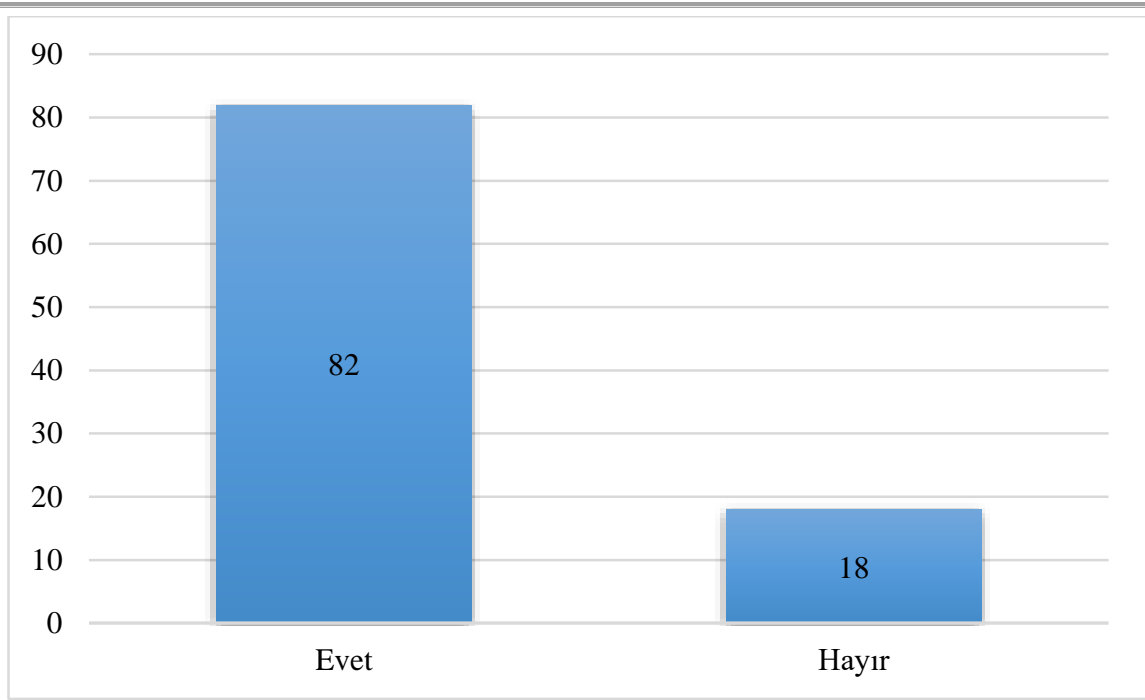

Şekil 7- Katılımcıların bütçe hesabı ve maliyet analizi ile ilgili olarak iç mimarlık lisans programlarının eğitim eksikliğine verdikleri cevaplar

- Son soruda, katılımcıların sadece \%20'si maliyet analizi için kullandıkları programlardan bahsetmiş ve \%80'i ise bu soruyu boş bırakmıştır. Program kullananların \%12'sinin Excel, \% 6'sının e-hakediş ve \% 2'sinin de İç Mimarlar Odası tarafından tanımlanan birim fiyatları kullandıkları saptanmıştır.

- İç mimarlık eğitim süresince maliyet analizi ile ilgili eğitim almayanların mezuniyet sonrasında çalıșmalarında nereden veya hangi programlardan destek aldıkları sorusuna \%79'u destek aldığı herhangi program olmadığı cevabını vermiștir. \%7'si patronu sayesinde, \%7 'si yetkili kişilerden (ofis arkadaşı, tanıdık, usta) \%7'si ise excel programından yararlandığını ifade etmiştir.

$\mathrm{Bu}$ veriye göre, katılımcıların güvenilir bir yöntem kullanarak bütçe hazırlama becerilerinin eksik olduğunu ya da mevcut pazardaki iç mimarlık projelerinin maliyet ve giderleri hazırlamak için belirli bir yöntemi kullanmada zorlandıkları sonucu ortaya çıkmaktadır. Her iki yöntemde de iç mimarlar arasında maliyet teklifi hazırlamak için özel bir yöntemin olmaması uygulama açısından büyük bir boşluk olușturmaktadır. Bu durum işverenlerin iç mimarların sunduğu maliyetlere ve dolayısıyla da iç mimara duydukları güveni de kaybetmelerine neden olacaktır. Anketlerden elde edilen sonuçlar hem uygulama hem de eğitimde maliyet analizi ve bütçe yönetimi ile ilgili fark1 vurgulamıştır.

- Katılımcıların cevapları, meslekleri için bütçe hesabı ve maliyet analizini çok önemli olduğunu ortaya koyarken, mezun olduktan sonra çoğunun gerçek pazardaki bedeller hakkında yeterli bilgiye sahip olmadıklarını ve bu nedenle bir bütçe teklifi hazırlama konusunda emin olmadıklarını göstermektedir. Pazarı anlamak için, belirli bir zamanı ayırarak yatırım yapmak yeni mezunlar için normal olmakla birlikte, bu konuda müfredattaki var olan boşluklar göz ardı edilmemeli ve doldurulmalıdır.

\section{Sonuçlar}

- Bütçe hesab1 ve maliyet analizi, iç mimarlar için önemli bir konudur. İnşaat aşamasında beklenmeyen durumlar nedeniyle, toplam maliyetin değişmesi normaldir. Ancak, proje maliyetindeki değişimin nedeni iç mimarın maliyet ve bütçeleme açısından bilgi eksikliği ise, sonuç iç mimarın kariyerine ve gelirine zarar verecektir. Türkiye'de her yıl artmakta olan iç mimarlık lisans programları bu sektörde yer edinebilme açısından zorlukları da 
arttırmaktadır. Projeler için uygun bir maliyetin hesaplanmasında bilgi ve beceri sahibi olmak, iç mimarların mevcut pazarda ayakta kalmalarına yardımcı olmak için daha da önem kazandırmaktadır.

- 50 iç mimar ile yapılan anket çalışması, katılımcıların maliyet analizi yapabilme becerilerinin profesyonel kariyerleri için çok önemli olduğuna inandıklarını ortaya koymasına rağmen, çoğunun mezun olduktan sonra maliyet analizi yapmak için yeterli bilgiye sahip olmadıkları da saptanmıştır.

Elde edilen sonuçlara göre katılımcıların çoğu, iç mimarlık lisans programlarında maliyet analiziyle ilgili boşluklar ve eksiklikler olduğuna inandıklarını belirtmiştir. İkinci ve üçüncü sınıflarda yer alan ve zorunlu olan yaz stajları öğrencilerin bu konudaki eksikliklerini tamamen giderebilmeleri için yeterli değildir.

$\mathrm{Bu}$ sonuç doğrultusunda iç mimarlık lisans programlarındaki derslerin yapısının, maliyet analizi ve bütçe yönetimi ile ilgili yeterli içeriği sunmak amacıyla geliştirilmesine ihtiyaç vardır. $\mathrm{Bu}$ araştırma aynı zamanda gerçek pazarda maliyet analizi konusunun dikkate alınmasının ve iç mimarlık mesleğinin gerçeklerine dayalı derslerin geliştirilmesinin önemini vurgulamaktadır.

- İç mimarlık/ mimarlık şirketleri yerine iç mimarların zanaatkârlar ve inşaat firmaları ile çalışarak maliyet analizinde becerilerini geliştirmeleri bu çalışmanın başka ilginç bir sonucu olmuştur.

- Bu sonuç, iç mimarlık ve mimarlık ofislerinde maliyet analizi ile ilgili metodolojilerde de eksiklik olduğunu işaret etmektedir. Bu sonuçlar pazardaki maliyet analiziyle ilgili bazı problemlere de işaret etmektedir. Katılımcıların ankette bir metodolojiden söz edememelerinin nedeni standart bir yolu izleyemiyor olmaları ya da belirli bir metodolojiyi kullanmak için hala yeteri kadar bilgileri olmamasına dayandırılabilir.

- Tüm tasarım alanlarında olduğu gibi iç mimarlık eğitiminde de öğrencinin tasarım yeteneğini geliştirme ve tasarımın iki ya da üç boyutta aktarımı yeterli olmayıp, uygulama dünyasına adım attıracak yöntemlerin/metodolojilerinin de öğretilmesi gerekmektedir. Öğrencilerin yaptıkları stajlar uygulama dünyasına ilk adımlarını attırırken, eğitimde de almaları gereken bilgi ve becerilerle daha da gelişmelerine yardımcı olacaktır.

\section{Kaynakça}

Baltacı, A. (2018). Nitel Araştırmalarda Örnekleme Yöntemleri ve Örnek Hacmi Sorunsalı Üzerine Kavramsal Bir İnceleme, Bitlis Eren Üniversitesi Sosyal Bilimler Enstitüsü Dergisi, 7, 231274.

Binggeli, C. (2007). Interior Design a Survey. Hoboken: Wiley.

Bozkurt, İ. ve Kuruoğlu, M. (2017). İnşaat Sektöründe Fizibilite Aşamasında Maliyet Tahmini Yapmakta Karşılaşılan Zorluklar ve Çözüm Önerileri Üzerine Bir Değerlendirme, $4^{\text {th }}$ Congress on Civil Engineer Management, Istanbul.

IMOB, https://www.icmimarlarodasi.org.tr

Improvenet. (2018). How Much Do Interior Design Services Cost? from https://www.improvenet.com/r/costs-and-prices/interior-designer-cost, Retrieved March 15, 2019.

Izadpanah, S. (2018). Perceptions About the Profession of Interior Architecture Before and After Education: A Study in Antalya, Turkey, 4th International Conference on New Trends in Architecture and Interior Design, St. Petersburg, 247-258. 
Lee, H-K, Lee, Y-S. ve Kim, J-J (2008), A cost-based interior design decision support system for large-scale housing projects, Electronic Journal of Information Technology in Construction, Vol. 13, 20-38.

Martin, C. (2019,). How Much Does Interior Design Cost? Retrieved from https://www.decorilla.com/online-decorating/interior-designer-cost/, February 26.

Michaels, J. V. ve Wood, W. P. (1989). Design to Cost. New York: John Wiley \& Sons.

Mitton, M. (2003). Interior design visual presentation: A guide to graphics, models, and presentation techniques. Hoboken, NJ: John Wiley \& Sons.

Piotrowski, C. M. (1992). Interior Design Management: A Handbook for Owners and Managers. New York: Wiley. 